\section{International Scientific Journal Theoretical \& Applied Science}

p-ISSN: 2308-4944 (print) e-ISSN: 2409-0085 (online)

Year: $2017 \quad$ Issue: $02 \quad$ Volume: 46

Published: $16.02 .2017 \quad$ http://T-Science.org
Vugar G. Karimli

Dr., associate professor culturologist

Scientific Secretary

Institute of Architecture and Art, Azerbaijan National Akademy of Sciences Azerbaijan, Baku, 1143, H.Javid ave., 31 yanshaq@gmail.com

SECTION 18. Culturology.

\title{
SYMBOLS AND BRANDS ARE MEANS OF EXPRESSION OF TURKIC PEOPLE ART CULTURE
}

Abstract: In the paper presented by author is stated the appearance of brands and symbols in ancient Turkic people since the period writing hasn't been existed yet. In Turkic people the fixing and functions of attributes have been fairly wide. The author comments widely related with statehood traditions, life manner, economical activity, military art and faiths of people, tribes or generations.

In addition, is told information about symbols and brands being a kind of art.

Key words: Turkish peoples, brand, symbols, art, ornaments.

Language: English

Citation: Karimli VG (2017) SYMBOLS AND BRANDS ARE MEANS OF EXPRESSION OF TURKIC PEOPLE ART CULTURE. ISJ Theoretical \& Applied Science, 02 (46): 46-48.

Soi: http://s-o-i.org/1.1/TAS-02-46-9 Doi: crossef https://dx.doi.org/10.15863/TAS.2017.02.46.9

\section{Introduction}

The greatest and charming work of the God is namely, the human being himself. And a human being is not the crown of the universe unique to its body, intellect and consciousness. One of the strengths of the human being is his creative ability. Art samples rather than scientific mind and workmanship are displayed enormously to be the human a grain of God. We all have enough knowledge about the kinds of art. Whether in the field of music, painting or architecture we are evidences and compatriots of such achievements that, instinctively, we have been included in the list of noble and civilized nations of the world. Nevertheless, there is a kind of art which we have less information about. These are symbols and brands which is famous as a kind of art culture in the Near and the Middle East, on a whole Turkish world, as well. These attributes are still insufficiently investigated. And study them can be one of the major factors, which facilitate to imagine of the real scene of our history.

\section{Materials and Methods}

With the lapse of time generations change, moral values are renewed, entire civilizations and cultures are displaced by others. But only ancient encoded symbols and attributes, their interpretations remain in memories. Humans initially, transferred through generations their opinion expressing not only with words but also by inscriptions and depictions. Both words and figures in our language or in the texts written by us are the symbolized forms, separately certain sounds with symbol book. One of the distinguished features of the human as a biological essence from other creatures is the ability to have abstract thinking, the occurrences around, any information on a whole; the idea and processes transfer to simplified characters and perceived symbol book.

Though these attributes belong to various social and cultural, intellectual levels, ethnic and cultural groups, time period and even if separate human communities, it was the effective means of communication for the ancient ancestors on a whole without distinction as national, religious and space. Human's realizing ability the environment through laconic characters and symbols is called 'mythic and poetic thinking' in science. About such a communication form obviously realized by everybody, well-known psychologist Erix From wrote: 'Language of symbols is a universal one best cognized of all the mankind' [1]. The oldest brands known by science as recognition and differentiation marks are about 5 thousand years old. American investigator James Horrod thinks that, in the old men's materially and morally world ordinary graphemes -letters formed on the basis of various sacral symbols, i.e., later on turned over alphabetic attributes, brands, hieroglyphs, ideograms, etc. And 
the initial shapes of these attributes have been embodied concrete events, rituals and processes namely, through their descriptions either different objects and creatures [6]. In old and famous general symbols, for instance, in alphabet attributes, in graphic pictures (in figures and letters) of quantity and sound investigation some reserved meanings, encoded holy messages caused forming of different religious and philosophical trainings as hurufism, kabbalah, numerology and has founded for itself a number of followers in poetry, music, colority, sculpture and architecture even in the trends based on esoteric traditions of conspirelogy. According to the science of psychology symbols including dealt with brand attributes are components of ancient people's mnemonic habits, i.e., save in memory and transfer method of large information through laconic and universal pictures.

Not only great ancestors, but also modern human has been covered with the most different symbols lighten his life, work and life mode; protect his health, time and security. Mnemonic- symbol book system is broadly being used in social and political, national, religious symbolism, in state symbols (in flags and emblems), in the modern computer technology, in the logos of companies and organizations, goods, traffic, in badges of military rank, in the information boards, and etc. A number of general attribute systems are quite realized by everyone. For instance, two inclined transversal line as in primary stage at the moment also means the sign of closed, beginning of the forbidden zone, the target sign in military, the hospital in public health, 'arrow' the direction, a snake clasping to bowl expresses health. Simple sign, which we can face in crowded streets in all countries and languages replaces by the long caution as 'no entry vehicles '. Among the differentiation symbols of celestial religions half-moon means Islamism, the Cross Christian, and Mogen David- Hz Davud's shield (in Islamism-Mohru-Suleyman) is considered one of the symbols of Judaism.

Let's look at the semantic of the other popular symbols. The "bitten apple" description logotype of the well-known company "Apple" embodies in one hand the apple, which encouraged Isaac Newton to detect gravitation power, in other hand mythic character of "guilty fruit" caused to Adam and Havva's exiling from paradise. Sometimes we also face to accidentally similarities. For instance, in North and South Caucasus, in Central Asia broad spreading "alban" brand in astrological symbolism has been adopted as a symbol of the Earth, and its turn down version the planet Venus. Furthermore, the logo of International Red Cross and Red Half-Moon Associations Union as "Crescent-Star" brand has decorated the surface of Goyturk coins specific to VI-VII centuries and Poland-Lithuania Tatars' emblems in the Middle Age. Symbol of Azerbaijani national manat and logotype of automobile company "Mazerati" resembles the attribute called "comb", "baltavar", "khan brand" of archaic Turkic tribes, the mark of the symbol euro, the signs of "bow-arrow" specific to Saka-Skiffs, Huns, Khazars, Oguz and Kipchaks inhabited in the areas lasting from Altays to Easten Europe, but the logo of "Sitroen" automobiles in France is the similar to best known "horseman" brand in Azerbaijan carpet ornaments.

In spite of various comments about the genesis, formation cause of ornaments considering art embodiment esthetical cognition of environment and mythic imaginations, in the initial stages namely, their sacral character was not discussion topic. It can be met the first samples of old ornaments in petroglyphs specific to Paleolith period, on the surface of crockery, stone and bony decoration objects detected during archeological investigations. In the cultures of Neolith they have been improved with new forms, different processing technique and application fields, reinforced symbolized significance, relations with primary religious faiths. As a result, today in the national applied art known as "national ornaments" in the semantic a number of ethnic design elements are being remained namely, our ancestors' ancient mnemonic symbols, brands and symbols, through alphabetic attributes codingtransmitted information. In particular, it is needed to emphasize that, brands, symbols and their derivatives ethnic ornaments are the important information source in the investigation of migration and integration processes, national art and history of specific nation. Brands are estimated as the sample of cultural heritage [7].

Though studying systematically of brand attributes prolonged about two hundred years several questions entirely identified, the discussion around them doesn't become slower yet namely, due to the fact of ethnic and political concerns. And the main reason is ethnic and cultural claims of ancient and rich materially and cultural samples, the areas located the very heritage, as well. Faithfully, brand attributes in order the chronological periods in identifying ethno genesis processes, ethnic culture, statehood traditions, faiths is an effective method both in incontrovertible evidences and ethno political struggle. Remark that, in comparison of the differentiation attributes of other peoples brand attributes of old Turkishs have more spacious functions. Whether brand attributes expressed in the peoples of Persian speaking, Caucasus speaking, in the Slavs mainly, on the property, cattle, individual or collective ownership in Turkish people, meant the first ethnic, generation and tribe ownership, religious and social origin, different individuals, generation and tribe status and etc. According the syntheses, fixing and functions of brand attributes were wide enough. It is feasible to meet them in various places related with statehood traditions, life manner, 
economical activity, military art and faiths of people, tribes or generations. For instance, on the battle flags and lord's pinheads; on armours, helmets and shields, upon blade of cutting arms; on the boundaries of forbidden zones and personal fields; on carpet and carpet productions, felts, silken clothes; upon decoration objects; on tattoos tattooing on parts of body, hand, arm, wrist, forehead; on pottery and jewellery; on headwears (caps and cowls/skullcaps); upon wedding garments, child clothes, mantles; on the walls of houses, kibitkas and tents, on the cracks of the doors; upon gravestones; in the places of religious faith; on make evil eye character objects; on haunch, forehead, ear and tail of neat and small horned cattle, horses and camels ; on harness means (carriage, bullock cart and etc.); in the entry of storehouse and cattleshed and etc.

Initial time these attributes as differentiating, property mark, to return evil eyes character, the greatest part to regard as being prototype of Goyturk alphabet graphemes have been lost their semantic over time, and in Turkish folks' applied art has laid foundation of the "rug and felt cryptograms" tradition. Because, art works weaving upon brand attributes ancient carpets, mats, rugs, and etc. apart from life merchandise are carriers of ethnic history of the whole people. One time each tribe, generation the living history has conveyed to loops in their weaving carpet products with excessive concern and respect, transferred the information to future generations. Therefore, feasible to meet specific to Turkish peoples a number of brand attributes and their hundreds of versions in ancient and contemporary applied art samples. Carpets, upon picture of faith symbol, make evil eyes, tribe or generation were not laid; they were hung on the walls of house, kibitka.

It's not accidentally, that well-known investigator of Goyturk memorials Abulfaz Rajablih called "engraved historical document of the whole Turkic speaking peoples" the texts written with the very alphabetical attributes. "These memorials are engraved history of old Turkic tribes, commanders', khanates' report of folk, declaration of Turkic genesis about the duties of state and folk, the sample of Turkic culture and military art improved in high level, the first page of Turkic fiction, public and philosophy opinion"[4].

\section{Conclusion}

As a result, one can imagine which ideology had great ancestors. Their legacy of art culture samples are the secret world for investigators of us. The art heritage of Turkic people is surely not investigated world and we are proud of with Turk's splendor, existence, history investigating this heritage.

\section{References:}

1. Qurbanov A (2013) Damğalar, rəmzlər ..mənimsəmələr. Bakı «SAM», 2013. 328 p.

2. Ofəndi R (2007) «Azərbaycan İncəsənəti». Bak1: "Şərq-Qərb", 2007,

3. Rəşidəddin F (1992) «Oğuznamə». Bakı, 1992.

4. Rəcəbli $Ә$ (2006) "Qədim türk yazıs1 abidələrinin dili». B., Nurlan, 2006. 648 p.
5. Yung K (1991) «Arkhetip i simvol». Izdatel'stvo «Renessans» SP «IVO-SiD», 1991.

6. (2017) «Tamga (Rodovoy znak) i Uran (Rodovoy klich)», Available: http://www.history.kz/ru.php (Accessed: 10.02.2017).

7. (2002) «Entsiklopediya simvolov, znakov, emblem».Avt.-sost. V. Andreeva i dr. M., 2002 